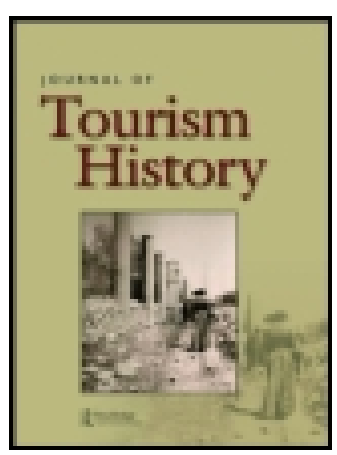

Journal of Tourism History

\title{
Signifying the small nation: the role of tourists in Luxembourgish national identity, 1913-1940
}

\section{Anne-Marie Millim}

To cite this article: Anne-Marie Millim (2016): Signifying the small nation: the role of tourists in Luxembourgish national identity, 1913-1940, Journal of Tourism History, DOI: 10.1080/1755182X.2015.1134681

To link to this article: http://dx.doi.org/10.1080/1755182X.2015.1134681

曲 Published online: 07 Mar 2016.

Submit your article to this journal $₫$

Џll Article views: 5

Q View related articles $₫$

View Crossmark data 


\title{
Signifying the small nation: the role of tourists in Luxembourgish national identity, 1913-1940
}

\author{
Anne-Marie Millim \\ Institute of Luxembourgish Language and Literatures, Maison des Sciences Humaines, University of \\ Luxembourg, Esch-Belval, Luxembourg
}

\begin{abstract}
This article explores the meaning of the tourist presence in the discursive construction of Luxembourg as a nation during the first part of the twentieth century. The Grand-Duchy of Luxembourg, a small territory surrounded by the major European powers France, Belgium and Germany, gained independence in the nineteenth century. The attribution of sovereignty made the invention of the nation imperative and landscape writing became instrumental in developing the ideological rootedness essential to the construction of national identity. Batty Weber (1860-1940), the most prolific contemporary writer, actively sought to shape the image of the independent Luxembourg both on a national and international level, drawing on the tourist industry as a means of acquiring national self-knowledge and self-respect. His assessments and suggestions for improvement regarding the practicalities of the tourist experience are of vital importance as they illustrate the process of creating places for foreign visitors and local residents alike. He further posited the imagined gaze of the tourist as the gaze the locals should adopt and advocated the 'spatial practices' (De Certeau) of visitors to be emulated in the enactment of nationhood.
\end{abstract}

\section{ARTICLE HISTORY}

Received 18 August 2015

Accepted 3 December 2015

\section{KEYWORDS}

National identity; tourism; locals; journalism; literature; Luxembourg

Tourism has a different impact in different contexts. Its influence goes beyond the numerically quantifiable and economically profitable and can penetrate deeply into an individual's self-perception as a social and a national being. The example of Luxembourg is pertinent for understanding the importance of mutually signifying interactions between tourists and locals, some of which happen without actual contact on a purely imagined and/or theoretical level. Significantly, Luxembourg's independence was not brought about by the assertion or rebellion of the (now) Luxembourgish people, but through diplomatic decisions made by the European powers. Because the genesis of the Luxembourgish nation-state occurred relatively late in the history of European nationalism, following a series of treaties (Vienna 1815, London 1839 and London 1867), it is possible to observe and trace the discursive creation of national identity as if from scratch. While Germany is also considered a 'young nation', taking shape in the nineteenth century, it was always substantiated by a history of empire. Luxembourg, on the other hand, had existed as a geographically distinct territory that was treated as a non-sovereign political entity when 
'legitimately' ruled by the Burgundians, Spanish, French and Austrians, thus existing without a history and without a distinct national identity. ${ }^{1}$ As Michel Margue has argued, in 1815, the population was not united by a collective consciousness of being 'Luxembourgers.'. Despite their discontents regarding the physical absence of the ruling monarch, the disrespect shown for their customs and privileges and the authoritarian character of the government, the population did not necessarily feel they were being 'dominated' by foreigners. ${ }^{3}$ By the second stage of independence in 1839, however, Luxembourgers worked actively to 'put the structures of an independent state into place and to develop the feeling of national belonging. ${ }^{4}$ Given the fact that the personal union with the Netherlands only ended in 1890 and Grand-Duchess Marie Adelheid (1894-1924), the first reigning monarch born in Luxembourg, only ascended to power in 1912 (she abdicated in 1919), the slow development of national and historical identity of post-independence Luxembourg becomes understandable (Figure 1$).^{5}$

The undeniably small dimension of the Grand-Duchy has constituted a fundamental factor in its national identity. Only from 1945, when Luxembourg formed alliances with other nations, such as the Benelux, and officially came to be recognised as an equal partner, questions regarding its right to exist ceased to dominate the discourse of identity. As André Linden has noted, the difficulty whether 'a disproportionately small country like Luxembourg [can] durably exist as an independent and sovereign political entity within the web of international relations' was prevalent before the Second World War. ${ }^{6}$ Such doubts caused a negative national sentiment which Linden sums up as such: 'to feel shamefully small compared to the big, to feel shamefully humiliated by the big, is the mental state of the damaged self-esteem of pre-war Luxembourg. ' The feeling of shame was no doubt fuelled by the difficult liminal position that Luxembourg occupied during the First World War. As an officially 'neutral' country, Luxembourg was demilitarised and did not, with the exception of 2000 volunteers fighting with the Allies, take part in military conflict. Despite this neutrality, it was invaded by 5000 German troops on 2 August 1914 and occupied for 4 years. During these years it was relatively sheltered from the bombings and massacres that devastated the neighbouring countries, but it had no political allies and its independence was acutely under threat. As Daniela Lieb, Pierre Marson and Josiane Weber have highlighted, Luxembourg's war literature of the period grapples with the shame of not having actively engaged in combat, reflecting feelings of inadequacy and guilt over the nation's cowardly endurance of adversity, particularly when compared with Belgium's martyrdom. ${ }^{8}$ In addition, the formation of national identity was severely challenged by the frequently shaky diplomatic construct on which sovereignty rested. In

${ }^{1}$ Pit Péporté, Sonja Kmec, Benoît Majerus and Michel Margue, Inventing Luxembourg: Representations of the Past, Space and Language from the Nineteenth Century to the Twenty-First Century (Leiden, Boston: Brill, 2010), 5.

${ }^{2}$ Michel Margue, 'Dominations étrangères' in Lieux de mémoire au Luxembourg: usages du passé et construction nationale, eds. Sonja Kmec, Benoît Majerus, Michel Margue, and Pit Péporté (Luxembourg: Saint-Paul, 2007-2012), 29-34, 29.

${ }^{3}$ Ibid.

${ }^{4}$ Ibid., 37. [My translation]

${ }^{5}$ Daniela Lieb, 'Der Erste Weltkrieg im Werk der Schriftsteller Willy und Max Goergen: Historisches Ereignis und literarische Repräsentation' (MA diss., University of Luxembourg, 2015), 99.

${ }^{6}$ Ibid., 203. [My translation]

${ }^{7}$ André Linden, "'Un beau PETIT pays"? Bilder und Diskurse um das Luxemburg der fünfziger Jahre', in Le Luxembourg des années 50: une société entre tradition et modernité (Luxembourg: MHVL, 1999), 197-244, 203.

${ }^{8}$ Daniela Lieb, Pierre Marson, and Josiane Weber, Luxemburg und der Erste Weltkrieg: Literaturgeschichte(n) (Luxembourg: CNL, 2014), 47. 


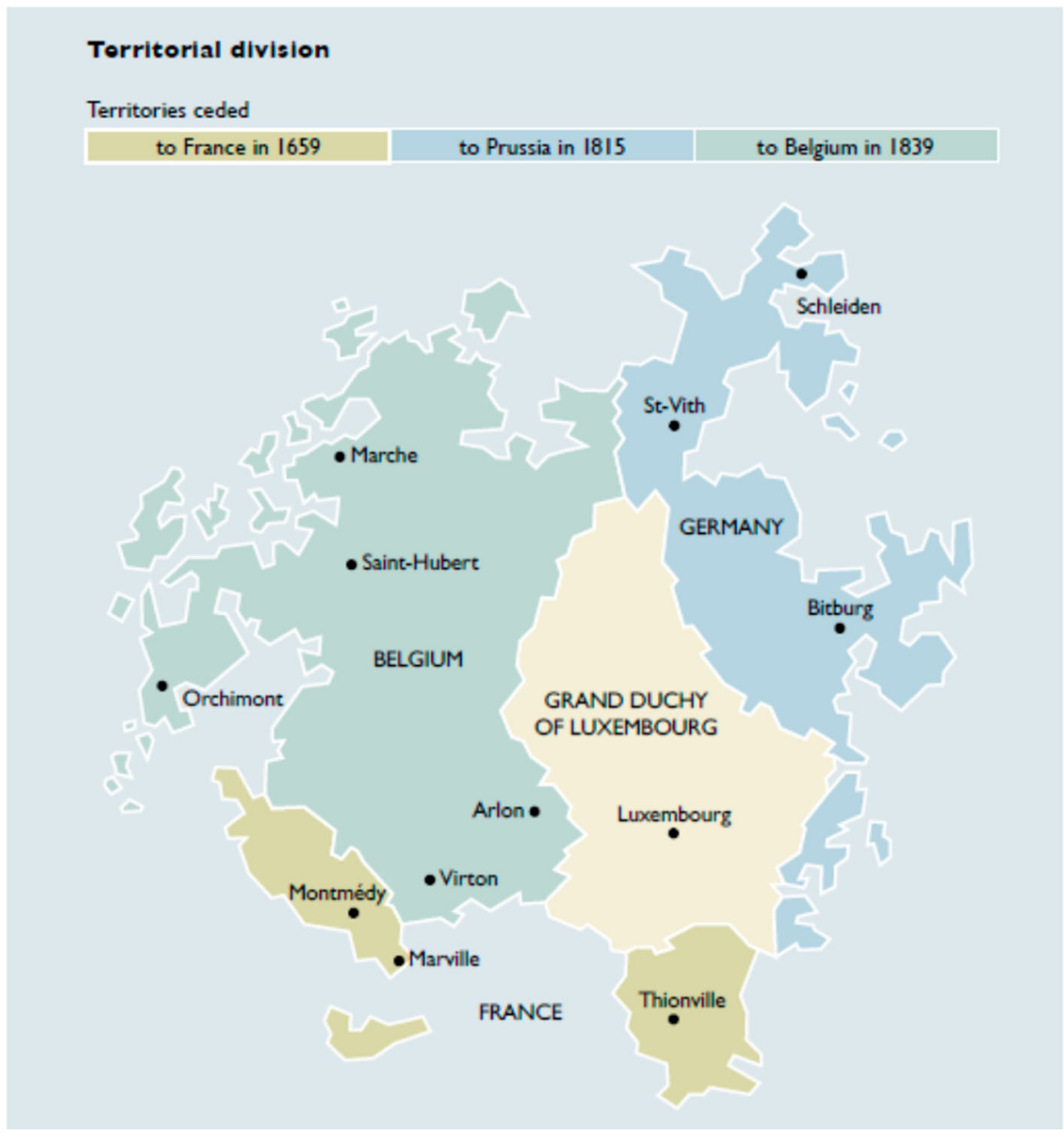

Figure 1. Map delineating the territorial changes undergone by Luxembourg in Guy Thewes, About ... [the] History of the Grand Duchy of Luxembourg (Luxembourg: SIP, 2008), 6.

the context of an ever-palpable minority and inferiority complex, national identity did not simply mean the pride in valuable cultural attributes and a sense of collective belonging, but the justification of the very existence of the Grand-Duchy. Hence, the judgement by others - tourists, visitors and foreign journalists - had a much stronger impact than it would have had on uncontested nations. The debate around the legitimation of the state, as Michel Pauly has explained, abated with the high death toll of the Second World War: 'after this war, no foreign government has ever questioned the independence of the country'. ${ }^{9}$ If the recognition of the nation in the end depended on military politics, it is preceded by intellectual and ideological efforts of self-definition that are reflected by and drawn out in the discourse on tourism. The transnational and transcultural relationships suggested, imagined and forged during the tourist encounter represent an opportunity for extrapolitical self-evaluation and self-presentation. 


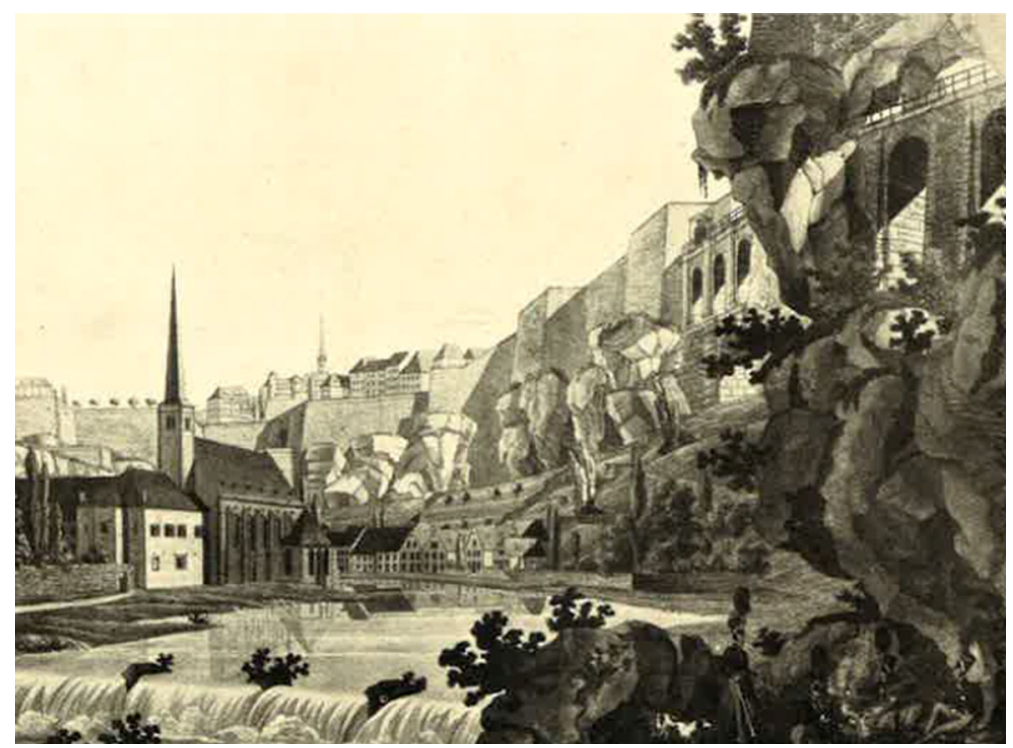

Figure 2. C.W. Selig [View of fortifications from Alzette Valley, drawn at the foot of the Bock] (23 September 1814), Cahiers luxembourgeois 1 (1934), 72 bis.

As is becoming clear, the process of inventing the Luxembourgish nation was a feat of collective agency that deserves attention. Without the backbone of military prowess and cultural expansionism, the master-narrative of the 'foreign dominations' from which Luxembourg had supposedly been liberated was instrumental in crafting an opposition between an oppressive non-Luxembourgish other and creating an imagined community of nationals deserving independence after suffering and dispossession. ${ }^{10}$ Literature, in inventing the national landscape, and the tourism industry, in highlighting the cultural assets of the nation for the first time, presented alternatives to historic alterity as nation-building factors. Both played an important part in giving the nation cultural substance by celebrating common possessions such as nature, natural beauty and ancient history. ${ }^{11}$ Another identity-forming factor, which cannot be discussed here, is the complicated multilingual situation of the now officially trilingual Grand-Duchy, defined by the coexistence of Luxembourgish (a Moselle Franconian language which has been given the status of national language in 1984), French (used in the administration and, in Batty Weber's times, by the intellectual elites) and German (primary language of scholarisation and the media) (Figure 2).

\footnotetext{
${ }^{10}$ See Michel Margue, 'Dominations étrangères' in Lieux de mémoire au Luxembourg (see note 2), and Péporté et al., Inventing Luxembourg (see note 1), 43-6.

${ }^{11}$ Myriam Sunnen, 'L'invention' du paysage luxembourgeois: littérature, tourisme, et nation-building à l'époque de l'entredeux-guerres', Unpublished plenary lecture delivered at the University of Luxembourg on 11 November 2011; 'De Minett comme lieu de mémoire', in Terres Rouges: approche interdisciplinaire et transnationale = Rote Erde: ein interdisziplinären und transnationalen Zugriff (Luxembourg: Fondation Bassin Minier, 2010), 9-19; 'Den Zolverknapp as kê Parnas: le paysage dans la littérature luxembourgeoise' in Identitäts(de)konstruktionen: neue Studien zur Luxemburgistik, eds. Claude D. Conter and Germaine Goetzinger (Differdange: Phi, 2008), 32-50; Anne-Marie Millim, 'Schooling the Gaze: Industry and Nation-Building in Luxembourgish Landscape Writing, 1900-1940', Journal of European Studies 44/2 (2014), 151-69.
} 
In order to anticipate my discussion of the role of the tourist figure in the construction of national identity, it is important to stress that the many generic similarities between landscape writing and tourist literature demonstrate the interface between a country's self-image and its image abroad. Much landscape writing of the period was addressed to a Luxembourgish audience, who, these authors felt, could benefit from being introduced to the country's natural and cultural particularities and needed guidance, initiation or 'schooling' for appreciating them as national possessions. It differs from writing geared towards tourists mostly in the formality of the publication venue and the artistic quality of the illustrations that accompany the text. The high-brow Cahiers Luxembourgeois: Revue libre des lettres, des sciences et des arts, founded in 1924 by writer Nicolas Ries, are an example of intellectuals' efforts to elevate Luxembourg's cultural and natural patrimony through sophisticated research, language and design. But daily newspapers, like the social democratic Escher Tageblatt, also regularly published landscape writing between 1900 and 1940. ${ }^{12}$ Generally, these texts do not provide information on hotels and restaurants but explicitly invite readers to observe and embrace an environment presented as their own. Perhaps not altogether 'ethnographic' in nature, due to its frequently semi-literary and rather non-scientific style, landscape writing does aim to 'produce authoritative knowledge' and 'recounts [the writer's] attempt[s] to conduct a visual ethnography of what is often seen as a visual practice'. ${ }^{13}$ Both types of writing tend to present written itineraries conveyed in a crafted, compelling and emphatic language. The Journal of the Touring Club Luxembourg (1897-1914, 1935-1939, 1950s) was somewhat exceptional in that it catered for a dual audience of locals and visitors, commissioning recognised writers to contribute articles of a high stylistic and historiographical standard - Batty Weber under his pseudonym Gummi Elasticum was one of them - and advertising hotels, bus services and train companies.

Perhaps more so than in other countries or national literatures, landscape writing and tourist literature seem to have followed a common agenda in the context in question: Luxembourgers, just like visitors coming from abroad, needed to be shown what sites and sights to consider representative of their national heritage. As Aloyse David and Marc Weydert have demonstrated, Luxembourg did not possess a culture of travel until the late nineteenth century. The political situation of closely successive reigns, as well as lacking transport and funds, had made travelling within the country, let alone exploring it for pleasure, quite difficult. Under the Spanish rule (until 1714), for instance, the residents of the geographic area now called Luxembourg were not allowed to leave their village or commune unless they 'bought their freedom', an impossible feat for many. ${ }^{14}$ Under the Austrians, who succeeded the Spanish, the freedom of movement of the citizens increased and allowed them to move to bigger, economically more active, towns that would develop into cities. After the invasion of the French armies in 1794 and the annexation to France (1795) as the département des forêts, feudalism ended but personal property, such as horses, had to be handed over to the rulers, who retreated in 1814. After independence

\footnotetext{
${ }^{12}$ Anne-Marie Millim, 'Sehen lernen: Landschaftsbetrachtung und Volksbildung 1913-1940', in Le Siècle du Tageblatt: Un Journal dans son Siécle, eds. Paul Lesch and Denis Scuto (Luxembourg: Tageblatt, 2014), 78-86.

${ }^{13}$ Mike Crang, 'Tourist: Moving Places, Becoming Tourist, Becoming Ethnographer' in Geographies of Mobilities: Practices, Spaces, Subjects, eds. Tim Cresswell and Peter Merriman (Farnham: Ashgate, 2012), 205-224, 206.

${ }^{14}$ Aloyse David and Marc Weydert, Alexis Heck: Begründer des Luxemburger Tourismus (Luxembourg: LTHAM and ALEDH, 2000), 15. [My translation]
} 
and particularly after the First World War, written renditions of nature walks, suggestions for itineraries, as well as poetic nature prose allowed for the visual and ideological appropriation of the national territory. Michel Engels and M. Huss's Picturesque Luxembourg, a portrait of the country of 1901, for instance, praises the 'privileged position' of independent neutrality and the 'natural beauty that is seldom found in such abundance in such small a place'. ${ }^{15}$ They consider the latter as 'real capital which could, if exploited correctly, bring real advantages to the country', manifesting an immediate association of quality with valuation by others. ${ }^{16}$ Arthur Hary, in the introduction to his collection Our Country: A Homeland-Book for Big and Small, posits natural beauty as the central pillar of national identity:

[This book] wants to tell of the beauties of our cities and villages, of homeliness and the people who lived in our dear homeland before us, it wants to recall the legends that grandmother told the children by the blazing fire. It wants to show how incomparably beautiful our Luxembourg is, it wants to fill every chest with holy pride, and with the firm and unshatterable will: We want to remain what we are [My italics]. ${ }^{17}$

The climactic slogan, coined by poet Michel Lentz mid-nineteenth century and since then persistently employed to stimulate national identity and cohesion, is here traced back to natural beauty, which is presented as the ideological backbone of the nation.

Much of Batty Weber's work as a feuilletonist inscribes itself into this tradition of nationalist landscape writing, playing a major role in the poeticisation of nature and the popularisation of Luxembourg's geographical, cultural and historical specificities. ${ }^{18}$ His writing was principally driven by one objective: to give Luxembourg a history. As he exclaims in his feuilleton of 28 April 1926, the country desperately needs more self-awareness, which could be concretised by a much-needed museum: 'A people without a history is a people that has not lived. And we have lived, we have a history, we even have stories' ${ }^{19}$ He was not to see a national museum established in his lifetime, but at the time of their publication, his feuilletons, capturing the everyday in Luxembourg for almost 30 years, must have instilled a certain foundation of knowledge and awareness in the audience, and perhaps, via transmission, the general public. His discussions of literature, art, history, economics and politics now serve a similarly preservationist purpose by offering a relatively direct glimpse into lived cultural history. Importantly, in countless feuilletons, Weber took his readers on nature and city walks, pointing out the beautiful and picturesque, inviting them to share his feelings of awe and thus cultivating a sense of national sentiment unrelated to military potential or the drive to conquer. While, as Danielle Hoenen-Gaasch has noted, Weber's audience was primarily the bourgeois intelligentsia of Luxembourg City, he also reached people of a working-class background as reprinted letters from readers show. ${ }^{20}$

\footnotetext{
${ }^{15}$ Michel Engels and M. Huss, Le Luxembourg pittoresque - Das Romantische Luxemburger Land (Luxembourg: M. Huss, 1901), 1. [My translation]

${ }^{16}$ Ibid.

${ }^{17}$ Arthur Hary, ed., Unser Land: ein Heimatbuch für kleine und große Leute (Luxembourg: Gustave Soupert, 1916), i. [My translation]

${ }^{18}$ Batty Weber's feuilletons have recently been digitised by the National Archives of Luxembourg and can be individually consulted online: http://query.an.etat.lu/Query/detail.aspx?ID=319614. For ease of retrieval, I will indicate both the date and the number of each text. All quotations by Batty Weber were translated by me.

${ }^{19}$ Batty Weber, 'Abreißkalender', Luxemburger Zeitung, April 28, 1926 (3166).

${ }^{20}$ Danielle Hoenen-Gaasch, Studien zu Batty Webers Abreißkalender (Esch-sur-Alzette: bound typescript, no publisher, 1977), 199.
} 


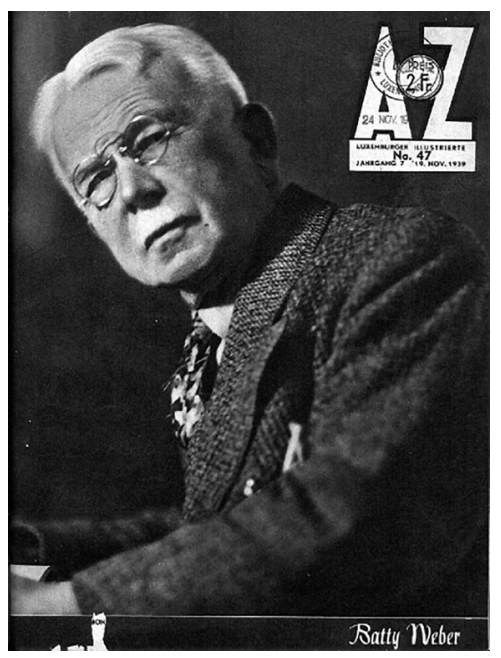

Figure 3. Batty Weber on cover of magazine, A-Z 47 (19 November 1939).

In his feuilletons, he frequently criticised or applauded public policies to do with urban development, landscape architecture and city hygiene. Although he may have had limited influence with the public administration, his critical eye and his humourously aired grievances awarded him the trust of his readers who often turned to him with their minor or major concerns, as his frequent publication of their letters shows (Figure 3).

Without question, Weber's writings had a great impact on Luxembourg's cultural life and the development of national identity. While his posthumous reception is overwhelmingly positive, critical voices during his lifetime complained about his dominance threatening to overpower and suffocate young critics and writers. According to linguist and educator Joseph Tockert (1875-1950), for instance, Weber possessed unparalleled insight into Luxembourgish society: 'If you want to talk about the Luxembourgish Soul, it is in Abreißkalender that you must look'. ${ }^{21}$ Poet Albert Hoefler (1899-1950) described Weber as having 'spoken to and moulded people from the height of his stand'. ${ }^{22}$ Many, like one journalist writing for the liberal Obermoselzeitung, saw him as the embodiment of the Luxembourgish type:

He personified our double-culture; he enriched our spiritual life a thousandfold; he is the most perfect representative of our national kind and if, one day, we had to justify our existence, we could proudly refer to this high-grade man who exemplifies best Luxembourgishness. ${ }^{23}$

This high praise shows that Batty Weber occupied a position of cultural authority, yet was generally considered very likeable: Pr. Schroeder portrayed him as 'surely the most cheerful philosopher ever produced by our homeland'. ${ }^{24}$ But there were other voices too, sarcastically characterising him as 'the old man of the Luxemburger Zeitung' who

\footnotetext{
${ }^{21}$ Joseph Tockert, 'In Memoriam Batty Weber, 1860-1940', in Annuaire de la Société des Amis des Musées (1949), 156-168, 156. [My translation]

${ }^{22}$ Albert Hoefler, Dichter unseres Landes 1900-1945 (Luxembourg: P. Linden, 1945), 23. [My translation]

${ }^{23}$ Anonymous, 'Batty Webers nationales Lebenswerk', Obermoselzeitung, November 25, 1939. [My translation]

${ }^{24} \mathrm{Pr}$. Schroeder, 'Batty Weber', Obermoselzeitung, December 18, 1940. [My translation]
} 
'knows better, because he knows everything; in fact, he is the only one to know anything' ${ }^{25}$ The conservative and strictly catholic Luxemburger Wort, in particular, frequently found fault with Weber's works, opinions and public appearances, which may, in part, have to do with the latter's scepticism and repeated criticism of the religious institutions.

As I have indicated, Weber's portrayals and expectations of the tourist industry are closely intertwined with his hopes and aspirations for the image of the country at home and abroad. His writings display and discuss a process of mutual signification that Mike Crang describes as inherent in the tourist-local interaction, as, for him 'the shaping of identity is a two-way process: we bring our backgrounds and desires but tourism also impacts upon our senses of selves' ${ }^{26}$ Indeed, Batty Weber's ideas for the improvement of tourist sites and infrastructure do not just have an economic objective. Rather, he suggests that through strategic self-marketing and, as we shall see, targeted 'nation-branding', the country would benefit from the approving gaze of tourists and improve its visibility abroad. This, in turn, would beneficially strengthen the locals' national identity as they themselves would learn about the country's heritage and feel empowered by the interest non-Luxembourgers take in them. As this article shows, Weber mainly reflects on the quality of the experience of actual tourists, but, significantly, he also constructs an abstract image of the tourist figure which serves as a model for the ideal gaze to be adopted by the local for productive self-perception.

\section{Historical awareness and nation-branding}

An analysis of Batty Weber's feuilletons can complement the historiography of tourism in that it does not just simply highlight the flaws and complications that could have been improved to benefit the tourist industry itself, but it underlines the firm integration of hospitality, rather than political strength and feelings of invincibility or superiority, into national identity and nation-branding. Weber's reflections reveal that in the public consciousness, Luxembourg's nationhood could not be justified without the foreign visitor. Slightly paradoxically, only by becoming a 'Fremdenstadt' [Strangers' City], could the homeland be, become and remain a home. Extrapolating from this idea, Weber encourages the locals to become strangers to their own country in order to perceive the aesthetic and cultural richness it has to offer. He has specific suggestions for crafting and guiding the 'tourist gaze', which John Urry describes as:

[presupposing] a system of social activities and signs which locate the particular tourist practices, not in terms of some intrinsic characteristics, but through the contrasts implied with the non-tourist social practices, particularly those based within the home and paid work. ${ }^{27}$

While the locals' intimate and professional lives tend to be portrayed as constitutive of the authentic place, Weber considers the 'tourist gaze' to be astute, perceptive and interested. The gaze of the other is therefore inherently superior to the mechanic, disinterested and indifferent gaze of the local, who often lacks the necessary openness to see the extraordinary in the familiar and thus to value his or her homeland appropriately.

\footnotetext{
${ }^{25}$ Anonymous, 'Kleines Feuilleton: Von jungen Kritikern und alten Herren: eine fröhliche Attacke gegen falsche Götter', Luxemburger Wort, May 1, 1934.

${ }^{26}$ Mike Crang, 'Cultural Geographies of Tourism', in The Wiley-Blackwell Companion to Tourism, eds. Alan A. Lew, C. Michael Hall, and Allan M. Williams (Chichester: Wiley-Blackwell, 2014), 71.

${ }^{27}$ John Urry, The Tourist Gaze: Leisure and Travel in Contemporary Societies, 2nd ed. (London: Sage, 2002), 1990, 2.
} 


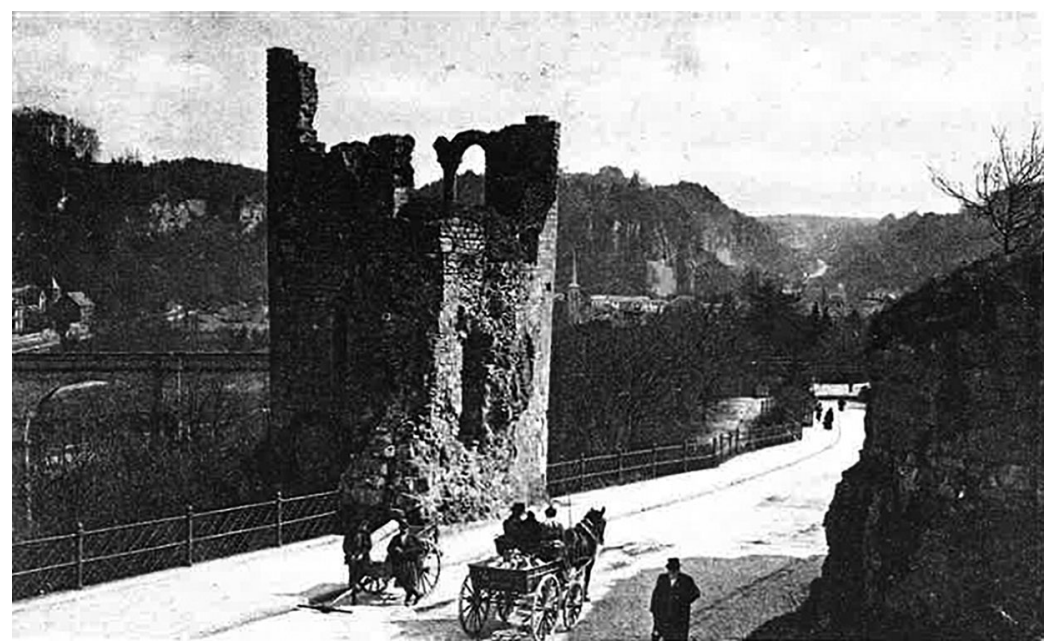

Figure 4. 'Luxembourg: Ruine du château sur le Bock' [before 1900] in Emile van der Vekene, Luxembourg-Ville en cartes postales anciennes (Zaltbommel, Netherlands: Bibliothèque Européenne, 1982).

The deliberate estrangement of the gaze that Weber proposes seems to have been acutely necessary. As the new parameters of the state demanded and encouraged the formation of a collective identity as a nation, the locals, just as much as visitors from abroad, depended on the socialisation of their gaze to discover, appreciate and value the perks of Luxembourg as a cultural location. According to Guy Thewes and André Linden, Luxembourgish institutions became conscious of the potential of cultural patrimony as tourist attractions and/or identity-building lieux de mémoire relatively late, as the demolition, executed 'without hesitation', of the 'most significant medieval building, the Franciscan Monastery' in 1835 proves. $^{28}$ They further advance the argument that it was visitors and artists inspired by the spirit of Romanticism who raised the national awareness of the cultural value of its many castles and ruins. ${ }^{29}$ In this sense, it was the 'gaze of the foreigner' that discovered and signified specific cultural locations, which could be claimed and prized as national possessions. ${ }^{30}$ Jean-Baptiste Madou's lithographs of Luxembourg, published in the 1822 Picturesque Voyage through the Kingdom of the Netherlands, for instance, were imitated by the Luxembourgish artists contributing images to Picturesque Voyage through the Grand-Duchy (1834-1836) and Picturesque Album of the Grand-Duchy of Luxembourg (1857). Before the end of the nineteenth century, castles, ruins and similar historical sites were inventoried, restored and frequently rebuilt. Sometimes, as in the famous case of the artificial ruin of the 'Hollow Tooth' on the Bock rock, sights were created 'ex novo'. ${ }^{31}$ While indeed a tower had once carried this name, it was situated at about $50 \mathrm{~m}$ distance. Despite the pretend-old addition to the structure, its base is about 600 years old, as Emile Van der Wekene has proposed (Figure 4). ${ }^{32}$

\footnotetext{
${ }^{28}$ André Linden and Guy Thewes, 'Tourismus und Nationale Identität', Ons Stad 88 (2008), 5-9, 6.

${ }^{29}$ See for instance Robert J. Casey, The Land of Haunted Castles (London: Leonard Press, 1924).

${ }^{30}$ Linden and Thewes, 'Tourismus und Nationale Identität', 6.

${ }^{31}$ Ibid., 7.

${ }^{32}$ Emil Van der Wekene, Luxembourg-Ville en cartes postales anciennes (Zaltbommel: Bibliothèque Européenne, 1982 ), 112.
} 


\section{Nation-branding}

The literature on nation-branding locates its objectives precisely in the interface of visitor and host, tourist and local. As Sue Curry Jansen explains, nation-branding is not solely interested in targeting 'international tourists, foreign investors and potential trading partners', but, crucially, also the 'citizens of the branded nation'. ${ }^{33}$ The latter thus receive an image of their country that is firmer and no doubt less complex than their individual experiences as citizens. In general, nation-branding depends on 'well-defined core meanings' that 'capture' the nation's 'desirable characteristics and image' as Lázló Kulcsár and Young-ok Yum note. ${ }^{34}$ In doing so, it generally seeks to 'eliminate the messy inconsistencies and cacophony of the multi-layered social interactions involved in developing national identities' as Jansen observes. ${ }^{35}$ Branded names, such as 'City of Roses' for Luxembourg City, 'Land of a Hundred and Thirty Castles' for the country, 'Land of Red Rocks' for the industrial South and 'Little Switzerland' for the rocky Müllerthal valley, in use during Weber's lifetime, indeed erase natural, social and cultural complexities by highlighting selected representational and signifying aspects of a city or region. Stephanie Hemelryk Donald, Eleonore Kofman and Catherine Kevin comment on this 'odd task' of nation-branding which is to create 'a limited patriotic identity, which must be sold to non-patriots wherever they reside, ${ }^{36}$ This deliberate limitation omits less desirable circumstances within the state, such as discords among communities, nationalistic fervour and social segregation, from the national brand and creates an idealised 'dream identity' reminiscent of the 'Disneyfication' of tourist sites of which Linden and Thewes, like many other scholars, speak. ${ }^{37}$ Evidently, as Zala Volèiè argued, this stylisation has a definite purpose:

Nation-branding has a double audience: the 'internal' population, so to speak, who are meant to relate to the brand as both a form of empowerment and a means of maximising the resources available to them; and an external population, for whom the brand is to serve as both an enticement to spend and invest [,] and a perception-controlling device. ${ }^{38}$

By thus controlling the response of foreign visitors to the country's attractions, the latter feed into the national identity of its citizens, creating a circle of signification in which meanings and images are created (Figure 5).

The study of national identity, nation-branding and tourism are thus closely interlinked as these fields at least partially operate based on invented and specifically tailored 'ways of seeing. ${ }^{39}$ As an interdisciplinary group combining literary scholars, historians and geographers has explained, the study of tourism allows access to the discourses 'that talk about

\footnotetext{
${ }^{33}$ Sue Curry Jansen, 'Redesigning a Nation: Welcome to Estonia 2001-2018', in Branding Post-Communist Nations: Marketizing National Identities in the 'New' Europe, ed. Nadia Kaneva (London: Routledge, 2012), 79-98, 79.

${ }^{34}$ Laszlo Kulcsár and Young-ok Yum, 'One Nation, One Brand? Nation Branding and Identity Reconstruction in Post-communist Hungary', in Branding Post-Communist Nations, 194.

${ }^{35}$ Jansen, 'Redesiging the Nation', 79.

${ }^{36}$ Stephanie Hemelryk Donald, Eleonore Kofman, and Catherine Kevin, 'Introduction', in Branding Cities: Cosmopolitanism, Parochialism and Social Change, eds. Stephanie Hemelryk Donald, Eleonore Kofman, and Catherine Kevin (New York: Routledge, 2009), 1-13, 7.

${ }^{37}$ André Linden and Guy Thewes, Greetings from Luxembourg: A Journey into the World of Tourism (Luxembourg: MNHVL, 2008), 35.

${ }^{38}$ Zala Volèiè, 'Branding Slovenia: "You can't spell Slovenia without Love ... "', in Branding Post-Communist Nations (see note 32), 159.

${ }^{39}$ John Berger, Ways of Seeing (London: BBC and Penguin Books, 1977).
} 


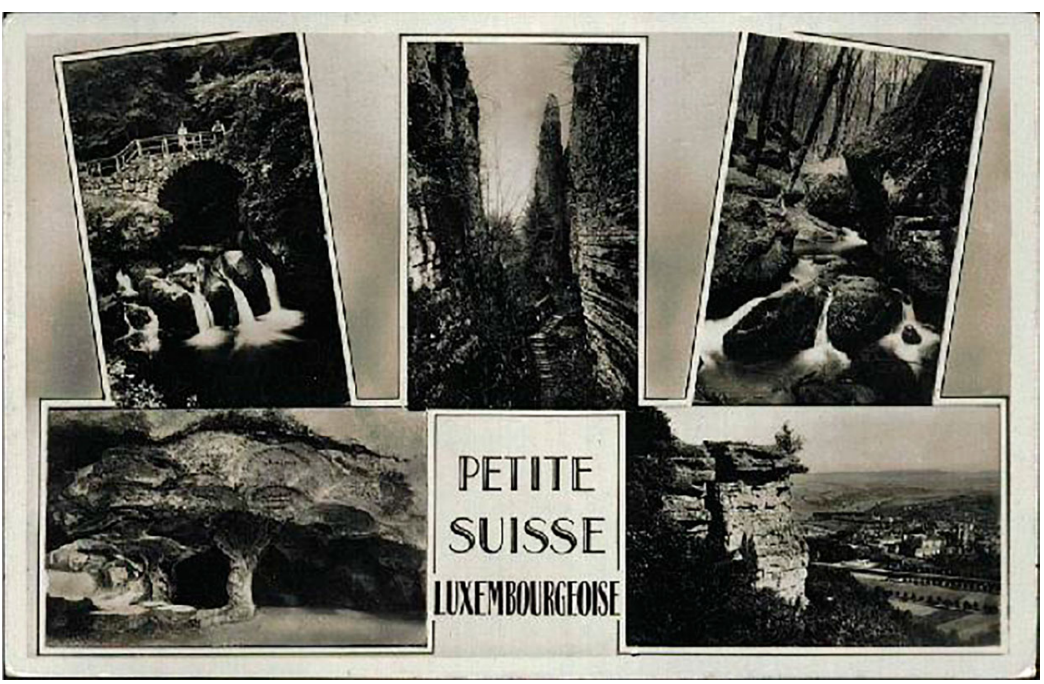

Figure 5. Undated postcard depicting the rocky Müllerthal area. $\odot B n L$.

space as such' and thus makes an examination of the nation's collective relationship to itself possible:

Tourism aims in particular at enhancing, defining and characterising space in a way more direct and explicit than is the case in politics or education. In short, as a subject matter for investigation, tourism is of immediate significance when we direct our attention to questions of identity [such as] to the dynamics of discursive production in defining what is 'Luxembourg'. [... ] In other words: tourism discourse has to convince others of the country's worth, [while it pretends] to provide [an objective] status report. This explains the significance that tourism has for the study of the attribution of meaning: [reports on tourism] inform about something by emphasising its importance, singularity or authenticity through argumentation; here 'objectivity' is thus quite clearly constructed and negotiated. ${ }^{40}$

It is clear that tourist posters, brochures and other paraphernalia, to a varying extent, inculcate visiting foreigners with a pre-conditioned gaze that prevents them from forming an appreciation that is fully their own - if such an individual-driven 'way of seeing' or a Ruskinian 'innocent eye' is indeed ever possible. These advertising materials, as well as the guidebooks, maps, postcards and souvenirs that frame the tourist experience, have been shown to direct the gaze towards selected sights, with the objective of triggering the awe, respect and excitement for what is to be perceived as Luxembourg's 'culture'. The focus of this study, however, lies on the consideration and employment of the tourist as a factor in nation-building, which is why tourist propaganda cannot be analysed in detail.

\section{Tourism in Luxembourg: economic and infrastructural development}

The historiography of tourism in Luxembourg has taken into consideration the types of visitors travelling to Luxembourg, the propaganda and public funds geared to attract

\footnotetext{
${ }^{40}$ Marion Colas-Blaise, Sylvie Freyermuth, Sonja Kmec, Gian Maria Tore, and Christian Schultz, 'Spaces and Identities' in Doing Identity in Luxembourg: Subjective Appropriations - Institutional Attributions - Socio-Cultural Milieus, ed. IPSE Identitiés, Politiques, Sociétés, Espaces (University of Luxembourg) (Bielefeld: Transcript, 2011), 107-64, 108-9.
} 
them as well as the infrastructure and organisations set up to welcome them. As Roland Lacaf explains, Luxembourg has figured as a destination in cosmographies and itineraries since the sixteenth century. Since 1815, British, French, Belgian, Dutch and German visitors stayed in Luxembourgish hotels, but it seems that the Anglophone visitors were most likely to engage in sightseeing activities, whereas the neighbours were often on commercial or military missions. ${ }^{41}$ From the 1820s, newspapers demonstrate the beginnings of tourist advertising but this aspect of the industry really took off when the Grand-Duchy became connected to the railway network in 1859 and campaigns were designed employing literary celebrities and artists, such as Johann Wolfgang Goethe, Victor Hugo or the early Ausone, who had praised the country's beauty. As Rüdiger Hachtmann has explained, the construction of the railway was generally a 'premise for mass tourism' and is partly the reason for the strikingly great differences in development of the tourist industries of different countries. ${ }^{42}$ While Britain's railway originated in 1825, the German one started in 1835 and the French, Swiss, Spanish and Luxembourgish systems were developing in the 1850s. By this time, Portugal did not have a single engine. Hachtmann equates 'low railway density' with a 'substantial delay in economic and touristic modernisation'. ${ }^{43}$ Luxembourg's railway expanded from $35 \mathrm{~km}$ in 1859 to $400 \mathrm{~km}$ in $1939 .{ }^{44}$ Due to the small surface of the Grand-Duchy, it is however difficult to productively compare these figures with those of the bigger countries that Hachtmann presents. Jérôme Anders writes in 1932 that for a country of its size ( $82 \mathrm{~km}$ in length and $54 \mathrm{~km}$ in width), Luxembourg possesses a railway network that is 'extremely dense and completed by bus services that serve almost the entire country. ${ }^{45}$ Transport historian Yvan Staus explains that the first train lines were designed for freight transport but that with the development of certain sites, like the Mondorf Spa, schedules and special tariffs catered to the needs of tourists rather than to those of the local population. ${ }^{46}$ During Batty Weber's times, bus transport was also very important for tourism. As distances were short, Luxembourg instituted subsidised buses to replace mail coaches as of 1910. Unsubsidised private companies ran special tours for tourists during the relevant seasons. It is certain that, as Linden and Thewes hold, the number of foreign visitors rose significantly with the development of the railway (Figure 6). ${ }^{47}$

The nineteenth century witnessed the formation of organisations related to tourism and travel, such as different Verschönerungsvereine (embellishment/improvement societies, from 1877), the Vélo Club Luxembourg (1884), or the very important Touring Club Luxembourg (1896). These associations, as Linden and Thewes have explained, devoted themselves both to the promotion of tourism and the preservation of historical patrimony. ${ }^{48}$ They were instrumental in the creation of rambling paths, accommodation and leisure infrastructure, and were particularly concerned with developing the principal tourist

\footnotetext{
${ }^{41}$ Roland Lacaf, Le Tourisme au Grand-Duché de Luxembourg: Histoire, Politique et Publicité Touristiques: des origines à 1952 (Luxembourg: Institut Universitaire International Luxembourg, 1972), 24.

${ }^{42}$ Rüdiger Hachtmann, Tourismusgeschichte (Göttingen: Vandenhoeck \& Ruprecht, 2007), 71. [My translation]

${ }^{43}$ Ibid., 74.

${ }^{44}$ Service Central de la Statistique et des Etudes Economiques, Statistiques Historiques 1839-1989 (Luxembourg: Ministère de l'Économie, 1990), 294.

${ }^{45}$ Jérôme Anders, 'Notre Industrie du Tourisme', Bulletin du Touring Club Luxembourgeois 1 (November 1932), 1-3, 2. [My translation]

${ }^{46}$ Yvan Staus, email message to author, 9 July, 2015.

${ }^{47}$ Linden and Thewes, 'Tourismus und Nationale Identität', 4.

${ }^{48}$ Ibid, 6.
} 


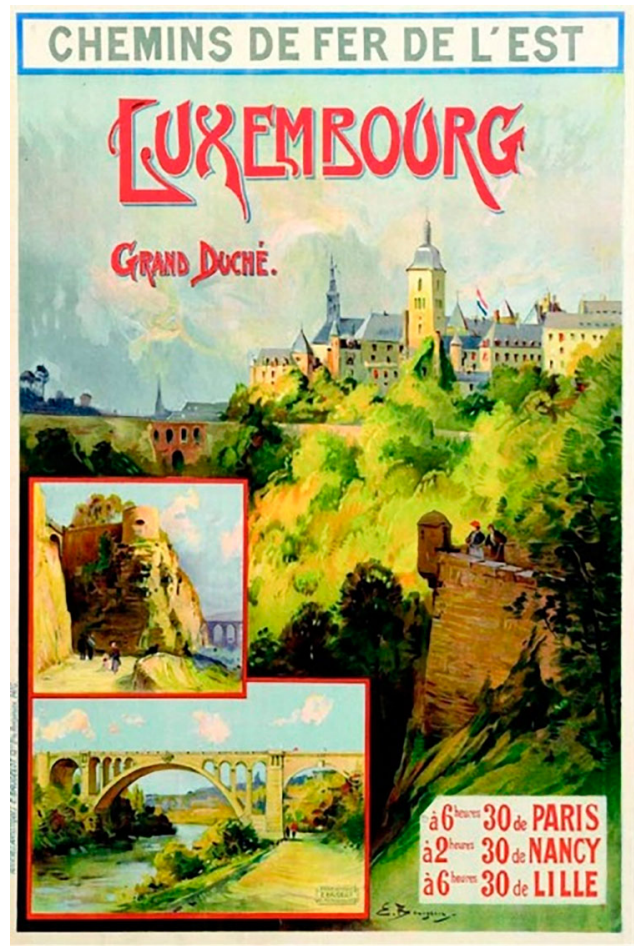

Figure 6. Advertising poster by French railway company depicting remnants of the fortress, as well as the Adolphe Bridge, the first one-arch bridge in Europe at the time of its completion in 1903. Ca. 1930s, OBibliothèque nationale du Luxembourg.

centres of the nineteenth century: Luxembourg City, Diekirch, Mondorf and Echternach. In 1898 Luxembourg hosted the International Congress of Tourism, sponsored by the government, at which delegates from French, Belgian, German Austrian, Swiss, Swedish, British, Russian, and American tourist and leisure organisations debated the need for a Union. ${ }^{49}$

In Luxembourg, the nineteenth century brought considerable progress in terms of hospitality but, as elsewhere, the industry came to a halt with the First World War. It resumed with renewed vigour due to a general rise in disposable income and the consequential democratisation of travel. By 1939, as Lacaf reports, Luxembourg had a population of about 300,000 and was able to accommodate 10,000 people in 5000 rooms in 277 hostels and hotels. ${ }^{50}$ This situation demonstrates an improvement of about $125 \%$ since $1905 .^{51}$ While between 1890 and 1914, tourists tended to stay for about three weeks, as for instance in the Hôtel des Ardennes in the Northern Diekirch, after 1918 they stayed for shorter periods but came more frequently. Lacaf distinguishes between two phases of tourism, an assessment that has been adopted by other scholars since. The first phase (1918-1928) is characterised by timid tourism politics on the part of the

\footnotetext{
${ }^{49}$ Congrès International de Tourisme (Ile session) 3, 4, 5 April 1898 (Luxembourg: Th. Schroell, 1898).

${ }^{50}$ Lacaf, Le Tourisme au Grand-Duché de Luxembourg, 84.

${ }^{51}$ Ibid.
} 
government and a majority of private initiatives. The second one (1929-1939) demonstrates a much more consistent government involvement as the crisis of the 1930s, when takings dropped by $20-30 \%$, made the economic and social importance of tourism all the clearer. ${ }^{52}$ The foundation of the Union des Villes et Centres Touristiques du Grand Duché de Luxembourg (Today's Office National du Tourisme) in 1931, working closely with the Belgian and Dutch Tourist Offices, is a product of a general willingness to strategically exploit tourism as a resource. According to Robert L. Philippart, the Union had 18 members in 1933 and was composed by several regional entities. ${ }^{53}$ The Union, as well as all tourist-related societies were dissolved and fused into the 'Landes-Fremdenverkehrs-Verbund Gau Mosel-Land' (Tourism Board of the Greater Moselle Region) under the Nazi occupants in $1941 .^{54}$

It is clear that these historical and economic facts constitute useful indicators of tourism's position in the country's priorities. Nevertheless, they cannot render the impact of tourism on national identity. While this study does not pretend to delve into the subjectivity of historical individuals, it can nevertheless illustrate the ways in which the notion of hospitality, as in the giving act of welcoming strangers into one's homeland, and the locals' need to be internationally recognised and respected coincide in tourist practices. Tourism is not only to be thought of as a 'way of seeing' sites, but also as a way of visualising and presenting the characteristics of nationhood.

\section{Missed opportunities: names and naming}

Abreißkalender is a testimony to Weber's consistent efforts to root the nation in its past and present, allowing nationals to conceive of a future as a cultural body. Weber does so partly by shaping a collective memory to unify the nation on an emotional and ontological level. ${ }^{55}$ Through sentimental reminiscences, such as memories from childhood, thoughts on the cultural importance of everyday items and reflections on customs and place names, Weber seeks to create a community of knowers who share the web of stories, objects and traditions they come to identify with as typically Luxembourgish. Beyond these attempts to ground the nation in a feeling of belonging to a community based on cultural heritage, Weber also appeals to the readers' sense of responsibility and cultural heritage. Repeatedly, he insists on the importance of creating a visual archive of buildings authorised for demolition so that these cultural sites can remain in the public mind instead of disappearing into nothingness, depriving the country of a grasp of its own past. With some exceptions, his frequently voiced demands for photographic historiography and for a more respectful attitude to Luxembourg's cultural patrimony were ignored by the state architect and the institutions in charge. Nevertheless, Weber's feuilleton surely raised the readers' awareness of Luxembourg as a place in which events and objects of cultural value were created. Thus counteracting the sense of cultural inferiority, at times accompanied by rampant arrogance, which, in his

\footnotetext{
${ }^{52}$ Ibid., 103.

${ }^{53}$ Robert L. Philippart, 75 ans ONT [Office National du Tourisme]: Histoire de la promotion touristique nationale (Luxembourg: Saint-Paul, 2006), 13.

${ }^{54}$ lbid.

${ }^{55}$ Anne-Marie Millim, Batty Webers Luxemburg = Le Luxembourg de Batty Weber (Luxembourg/Mersch: CNL, forthcoming 2016).
} 
opinion, led to the unforgivable habit of Luxembourgers to ignore and forget their past, Weber's feuilleton acts as a reservoir of daily vicissitudes and disappearing customs, making visible unconsciously adopted traditions. ${ }^{56}$

Weber's conviction that national identity in part depends on the nation's self-presentation to the outside world fuels his critical assessments of the ways in which Luxembourg did or did not 'play to the gallery'. Terminology, slogans and names are evidently essential in creating places that ground the nation, both for tourists and for locals. Accordingly, Weber advises care in attributing such durable meanings to elements of the public sphere. One of his grievances, frequently voiced in his feuilleton series, is the supposed inability of the institutions in charge to render public spaces useful, educative and attractive enough. One feuilleton from 1923 starts with the provocative matter-of-fact statement that includes all Luxembourgers: 'We do not know how to present ourselves to others. We have no sense of self-assertion'. Drawing the reader in by a fatalistic and reproachful tone, Weber goes on to explain: 'Our entire city with all its particularities to this day is in many ways a buried treasure. Because we have no talent for staging ourselves' ${ }^{57} \mathrm{He}$ admits that his 'far-fetched, pessimistic observations' were triggered by a 'really very minor circumstance', namely the fact that the room in the 'Palais municipal' in which the Council of Luxembourg City holds its meetings is simply called after its wall furnishings: 'the wooden room'. ${ }^{58}$ Weber deplores the missed opportunity of not dedicating rooms to meritorious citizens, such as Servais, Brasseur and Mousel, in order to honour them and educate the citizens, giving them a sense of heritage and identity. ${ }^{59}$

While Weber recognises the importance of marketing sites as exciting and educative experiences to be acquired, he nevertheless deconstructs some of the tourist slogans that, in his opinion, veil the site or region by grandiloquence and inaccuracy. This misnaming of national assets as part of nation-branding strategies might still, or perhaps especially, attract foreign visitors, but it distorts their authenticity and therefore misinforms and alienates the locals. In his feuilleton from 1929 he criticises an instance of incongruence between national identity and nation-branding:

We do not know how to present ourselves. There are exceptions. But in general we do not. National flaw, national virtue? Depends. Let's take our Müllerthal and its surroundings, for instance. We think we have done ever so well when we have posters made that say: Little Switzerland. This is first of all untrue, because the region is nothing like Switzerland. And moreover it is silly to devalue a particularity by comparing it to something else. ${ }^{60}$

As Lacaf and Philippart confirm, the state had indeed repeatedly invested comparably big sums into advertising campaigns, sponsoring the design, production and dissemination of posters and brochures. Weber considers that this aggressive nation-branding is not indicative of successful or even flattering self-presentation, because it lessens the local distinctiveness of the spot by making the original name secondary to the overarching marketing concept created to sell the region.

\footnotetext{
${ }^{56}$ Anne-Marie Millim, 'Batty Weber: der Abreißkalendermann als Erinnerungshistoriker', in Batty Webers Luxemburg (see note 54), n.p.

${ }^{57}$ Batty Weber, 'Abreißkalender', Luxemburger Zeitung, May 25, 1923, 2403.

${ }^{58}$ Ibid.

${ }^{59}$ Guy Thewes, Les gouvernements du Grand-Duché de Luxembourg depuis 1848 (Luxembourg: SIP, 2011).

${ }^{60}$ Batty Weber, 'Abreißkalender', Luxemburger Zeitung, February 7, 1929, 3898.
} 
Weber's feuilleton frequently observes a generalised lack of desire to attract favourable signification from foreign visitors. Despite substantial investment into tourist campaigns, he notes the failure to sell the essentials necessary for a satisfying tourist experience of a certain duration. In his eyes, 'foreigners are our suitors' and one of the greatest flaws of the generalised collective national persona that Weber terms 'us Luxembourgers' is the failure to maximise the country's tourist potential: ${ }^{61}$

These days we have to be ashamed of ourselves again. Because we do not know how to use our talents. One talent that has been given to us is the unique panorama in which our city is embedded. And what do we do with it? Sweet nothing. ${ }^{62}$

Weber bemoans the 'craziness' of ruining the most beautiful view points of Luxembourg City by thoughtlessly placed public buildings, such as the military barracks that block the picturesque view into the Alzette valley. ${ }^{63}$ Similarly, a customs office, a teachers' training college, a music school, a crèche, a hospital, a factory, a nursing home and a Jesuit monastery, among countless others, prevent the wandering gaze from enjoying the vistas. Weber's accounts show that the tourist experience was often marred by insufficient hospitality facilities; information that would be difficult to gather from quantitative studies of the tourist phenomenon. Weber describes a typical tour of the capital: 'Corniche [Ledge of the Bock rock], Three Towers, Terrace of the Pescatore Estate', which is dotted by the visitors' exclamations: 'Wonderful, amazing, stunning! One would like to spend days and weeks here!' ${ }^{64}$ To which Weber replies laconically, addressing his feuilleton audience: 'Not a chance! You cannot even stay for a cup of tea. Nor sit down for five minutes' ${ }^{65}$ Only one establishment offers refreshments in the proximity of the famous Corniche-walk, which Weber sarcastically calls 'the biggest attraction in Luxembourg'. He also calls it the 'germ cell' out of which Luxembourg could develop into a functioning tourist destination. The lack of initiative to provide essential catering for visitors or even to offer them pampering and comfort is a missed opportunity on an economic and organisational level. ${ }^{66}$ Convincing tourists to engage in ever different activities, be they related to entertainment or gastronomy, is crucial to becoming a 'Fremdenstadt' - a City for Foreigners. ${ }^{67}$

While, as I have indicated, according to Lacaf, the average tourist remained in the country for several days, Weber's impression is different. He describes a phenomenon that indicates that Luxembourg City was a busy train hub which many tourists visited 'between two trains'. ${ }^{68}$ He considered these flying visits as wasted opportunities for the country to draw in tourists and persuade them to stay longer and/or return. According to him, excessive advertising attracts tourists that find themselves disappointed or let down by the situation they find upon arrival. Weber asks a rhetorical question typical for his feuilletons:

When will it ever stop being the case that the foreigners, whose attention has been drawn to the beautiful and unique Luxembourg by ads, leave three to five hours after their arrival,

\footnotetext{
${ }^{61}$ Batty Weber, 'Abreißkalender', Luxemburger Zeitung, November 13, 1925, 3031.

${ }^{62}$ Batty Weber, 'Abreißkalender', Luxemburger Zeitung, April 17, 1930, 4222.

${ }^{63}$ Ibid.

${ }^{64}$ lbid.

${ }^{65}$ Ibid.

${ }^{66}$ Ibid.

${ }^{67}$ Ibid.

${ }^{68}$ Batty Weber, 'Abreißkalender', Luxemburger Zeitung, May 5, 1935, 5576.
} 
convinced to have seen Luxembourg, when they merely crossed one of the two bridges to the [Place Guillaume - William/Parade Square] ${ }^{69}$

Weber is irritated by the fact that advertising is a waste of money if the destination cannot keep the promises it makes. He finds the priorities of administrations and business owners to be misdirected when he criticises that at the end of the bridge that leads from the train station into the heart of the city tourists will find an advertising column where there should be an orientation panel to give visitors an overview of the site, its highlights and services. The missing panel is also the object of an anecdote in which Weber 'innocuously' observes a French couple of newlyweds. Watching them contemplate the colloquially termed 'Gölle Fra' (the Golden Lady), the monument commemorating volunteers fighting in the First World War, they briefly comment 'This, this is a monument', glance at the panel depicting Maréchal Foch's speech, and then the young husband consults his watch and advises they should make their way to the train station. ${ }^{70}$ Weber, who had expected them to exclaim 'Look at those Luxembourgers!' and applaud the military courage commemorated, is disappointed: 'I would have liked to tell them that they had seen practically nothing of Luxembourg - what would I not have told them so they did not leave..$^{71}$ In 1936, he again stresses the necessity for such a panel so that visitors do not leave having no clue of the beauties of the city. He therefore calls on a generalised interlocutor of readers, administrators and advertisers: 'Advertise abroad, pull out the big guns, draw in foreigners by the hundreds and thousands, but once they are here, make sure they find everything confirmed that you have been raving about'. ${ }^{72}$ Weber fears that advertising an unrealistic picture of Luxembourg by purely performing an idealised image will lead to a disappointing clash between expectation and experience. Keeping advertising campaigns flattering but genuine for him is part of accepting and appreciating one's own country (Figure 7).

Importantly, Weber does not criticise tourists embarking on an action-packed leisure holiday but rather the inability or unwillingness of the Luxembourgish institutions to cater to their interests and needs. In 1932, for instance, he comments on the irony of the new tourist propaganda office creating advertising that cannot keep its promises. While the propaganda, as well as many appraisals from (obliging) foreign commentators describe Luxembourg as a potential 'Garden of Eden, the ideal summer holiday destination, presenting the city and country, nature and culture very close together [etc.]', in reality it is a 'transit station, a site of boredom, forcing visitors to escape as soon as they have seen the beauties that form our richness. ${ }^{73}$ He therefore, for the 'thirtyseventh time', calls for more strategic entertainment: 'he who goes on a leisure holiday wants to be active. He does not want to be sitting around idly and receptively, hands in his lap. He wants to live, play, walk, run, dance, swim and so on'. ${ }^{74}$ Similarly, two years later, with growing impatience, he tries to persuade the national persona that 'we finally need to realise that the visitor looking for relaxation outdoors nowadays is no longer the passive tourist we keep imagining. ${ }^{75}$ The basic flaw underlying the misdirection of

\footnotetext{
${ }^{69}$ lbid.

${ }^{70}$ Batty Weber, 'Abreißkalender', Luxemburger Zeitung, April 14, 1934, 5292.

${ }^{71}$ lbid.

${ }^{72}$ Batty Weber, 'Abreißkalender', Luxemburger Zeitung, April 18, 1936, 5830.

${ }^{73}$ Batty Weber, 'Abreißkalender', Luxemburger Zeitung, November 16, 1932, 4903,.

${ }^{74}$ Ibid.
} 


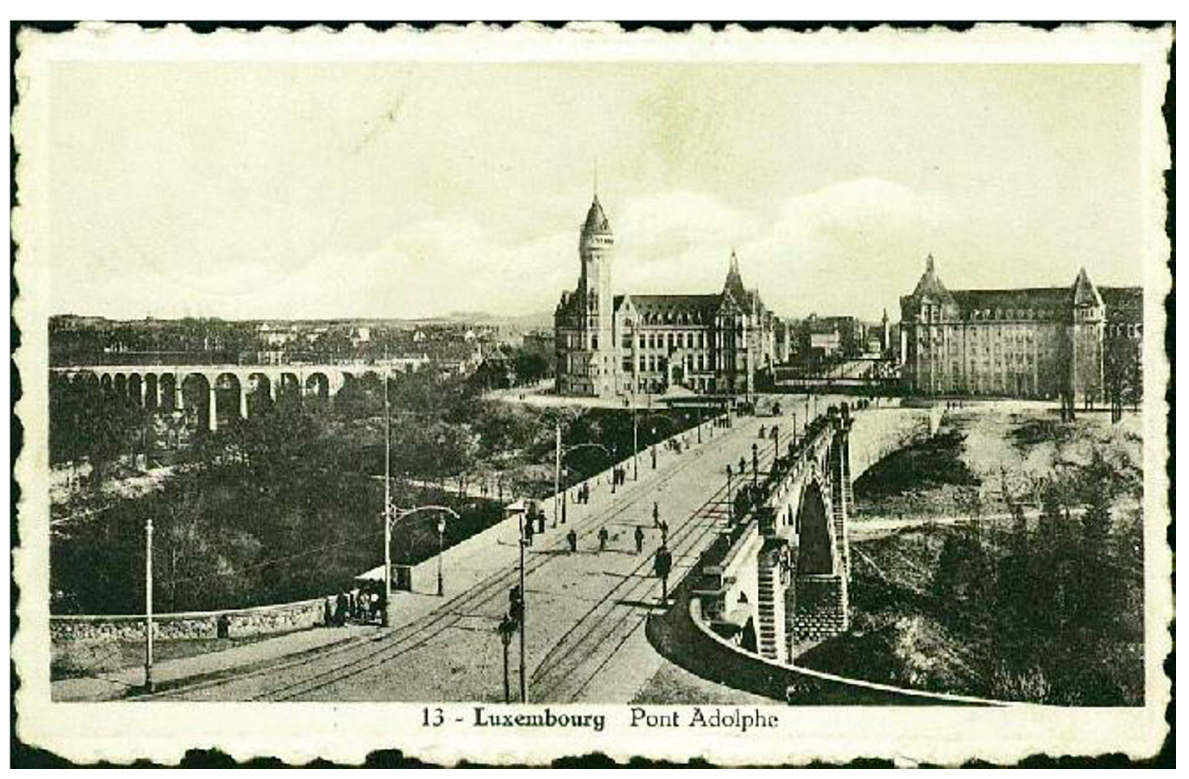

Figure 7. This postcard posted in 1943 pictures the two bridges that Weber mentions. The tower at the end of the Avenue de la liberte is the train station and the foreground of the image depicts the ideal spots for information panels according to Weber. $\odot B n L$

the efforts of the tourist industry is their premise. According to Weber, "here, the question of tourism has only ever been looked at from the point of view of Luxembourgish beneficiaries. For Heaven's sake, let's try and see it the way tourists would' ${ }^{76} \mathrm{He}$ 'sign[s] these lines pretty pessimistically VCID. Which means: Vox clamantis in deserto' ${ }^{77}$ As the president of the Swimming Club of Luxembourg City and as a passionate rambler, Weber led an active life himself. Displeased with the slow-pacedness of Luxembourgish institutions, he criticises the current offer of attractions and deconstructs the apparent belief that silent contemplation is the proper way to relax and appreciate a tourist site, which equates the country with a stuffy museum.

\section{Press, tourist materials and national identity}

Weber's concerns as to the construction of an appropriate image for Luxembourg abroad in part stem from upsetting articles about the country published in the press. Weber was very well-read and kept up with many international newspapers and publications. This is how he learnt about travel reports or presentations for tourists dealing with Luxembourg, often much to his dismay. He knew that visitors arrived in the country having formed desires and prejudices, and was aware of the far-reaching dimensions of tourism that Crang describes: 'tourism is not confined to 'destinations' or resorts, but bleeds into the rest of our lives. Travel is preceded by fantasies, hopes, anxieties, and expectations. After any travel there is a realm of memories and effects. ${ }^{78}$ The negative representation

\footnotetext{
${ }^{75}$ Batty Weber, 'Abreißkalender', Luxemburger Zeitung, May 5, 1933, 5045.

${ }^{76}$ Ibid.

${ }^{77}$ Ibid.
} 
of Luxembourg in the press was particularly problematic because for years no trustworthy tourist guidebook existed to keep tourists on the right path, both logistically and ideologically. Tourist manuals, as Rudy Koshar has explained, were 'designed to be transparent' and to discourage a confusing 'multiplicity of meanings while viewing particular touristic sites' ${ }^{79}$ With no authoritative guidance for visitors available, the 'referential proliferation' caused by reports lacking a disinterested perspective represented a threat to the reputation of Luxembourg. ${ }^{80}$ While, as Weber notes, 'everything was done' to further the tourist industry, 'the one thing, the most necessary of all, the most useful, was not done'. ${ }^{81}$ The instinctive grasp for a guidebook on Luxembourg, for many an essential tool for travel, was futile for years after the First World War. Alexis Heck, a visionary hotelier who helped to transform the Northern Diekirch into the tourist hub it is today, published a guidebook in English and one in French in 1893 as part of his successful business strategy. ${ }^{82}$ There seems to have been but one edition of these guides and it is uncertain whether they were distributed outside of Luxembourg. The Baedecker and Woerl guides devoted to the Grand-Duchy were out of print in the early twentieth century and it was not until 1934, when a new edition of the Woerl guide was published, that Luxembourg was officially back on the tourist map. The French publisher Hachette first released a guidebook of Luxembourg in 1895, followed by one that combined Luxembourg and Belgium and devoted about 40 of its 450 pages to the Grand-Duchy.

During the years without the authoritative representation by a guide book, the visitors' preliminary perception of Luxembourg was influenced by the defamation by journalists, which would have had an impact on the national identity of the locals. According to Weber, the problem of inadequate appreciation was exacerbated on the ground, where the multitudes of tourists visiting Luxembourg were forced to go off on a mystery tour, 'seeing but half of what is noteworthy, experiencing aesthetic and material disappointments, being cheated left and right and leaving the country disgusted'. ${ }^{83}$ Conceived with 'understanding and love for the cause' by a specialist writer, who travelled the country for a year, the new edition of the Woerl was extensively revised in collaboration with local associations and institutions and, for Weber, constitutes a 'precious gift' for Luxembourg. ${ }^{84} \mathrm{He}$ even recommends it to the locals, warning that visitors in possession of the guide might know more about the country than they do. He sees it as a national duty to thank Mr Peters and the Woerl publishing company for 'creating a work that does justice to our homeland on the inside and the outside', thus 'compensating' for misrepresentations, superficialities and thoughtless or malicious needling by 'arrogant' journalists. ${ }^{85}$ Weber highlights another positive depiction by Oskar Richardt for a Cologne newspaper, the Kölnische Zeitung, which, in comparison to the frequent mockery of Luxembourg displayed by other papers, earns his deeply felt gratitude. Richardt writes that 'Luxembourg needs to be lived, not just visited in a rush' and thus confirms Weber's own point. ${ }^{86}$ The latter's reproduction of large

\footnotetext{
${ }^{78}$ Crang, 'Cultural Geographies of Tourism', 72.

${ }^{79}$ Rudy Koshar, '“What ought to be seen": Tourists' Guidebooks and National Identities in Modern Germany and Europe', Journal of Contemporary History 33/3 (1998), 323-340, 326.

${ }^{80}$ lbid.

${ }^{81}$ Batty Weber, 'Abreißkalender', Luxemburger Zeitung, April 21, 1934, 5298.

${ }^{82}$ David and Weydert, Alexis Heck.

${ }^{83}$ Batty Weber, 'Abreißkalender', Luxemburger Zeitung, April 21, 1934, 5298.

${ }^{84}$ Ibid.

${ }^{85}$ Ibid.
} 


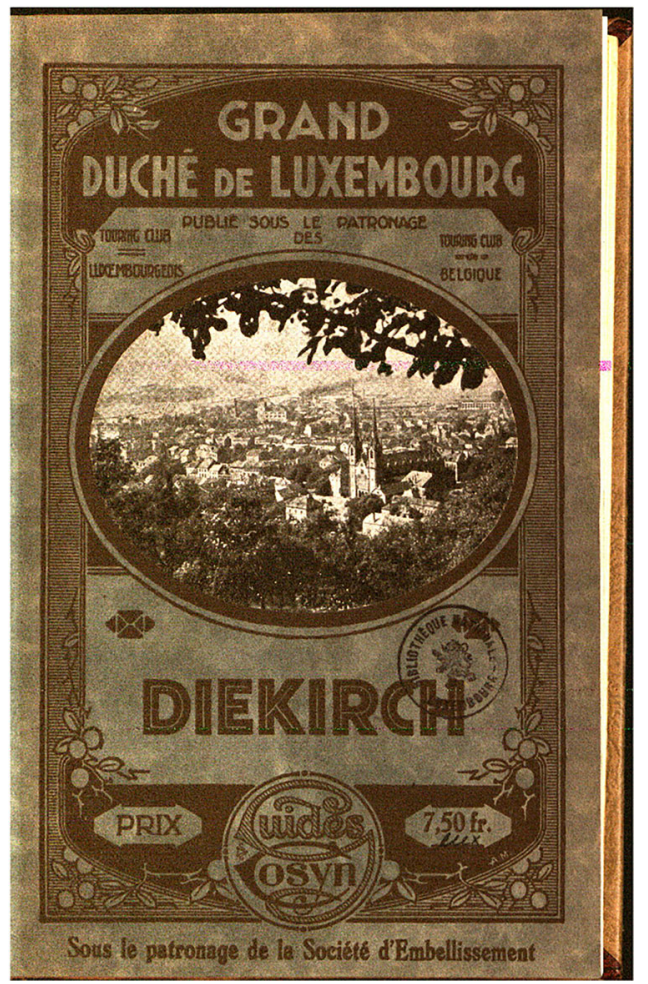

Figure 8. Travel guide by Maurice Cosyn of 1933.

chunks of the glowing review, which takes up about three quarters of the feuilleton, proves that the image of the country, in his eyes, needed to be improved as much within as outwith its borders. Weber similarly thanks Maurice Cosyn, who created of tourist paths throughout the country ('A foreigner had to come to mark the prettiest walks'), and bemoans the omission of Luxembourg City from this project until the late 1930s: 'our cultural capital in natural beauty lies dead for many, who are left to their own devices' (Figure 8). ${ }^{87}$

One example of such scathing reviews, entitled 'A Very Small Capital', was published by René Kraus in the German Stuttgarter Neues Tageblatt in 1929. The author mocks the country's 'mixed culture' (Mischkultur), a concept of collective identity that Weber helped to coin in 1909 and which describes the national character as fusing German and French elements with uniquely Luxembourgish cultural attributes, such as its language. He explicitly stresses the 'stupidity' of the journalist, whom he categorises as a part of the species of 'idiots who come to Luxembourg between two trains and concoct clichéd banalities for 15 pence a line'. ${ }^{88}$ Kraus portrayed the presence of the French language and customs as offensive for German culture; for instance, he speaks of an 'arbitrary translation of first names into French' as an 'official deformation of the good German last names' that Luxembourgers supposedly possess. ${ }^{89} \mathrm{He}$ derides

\footnotetext{
${ }^{86}$ Batty Weber, 'Abreißkalender', Luxemburger Zeitung, April 18, 1936, 5830.

${ }^{87}$ Batty Weber, 'Abreißkalender', Luxemburger Zeitung, February 26, 1938, 6325 and July 5, 1935, 5625.

${ }^{88}$ Batty Weber, 'Abreißkalender', Luxemburger Zeitung, October 12, 1929, 4069.
} 


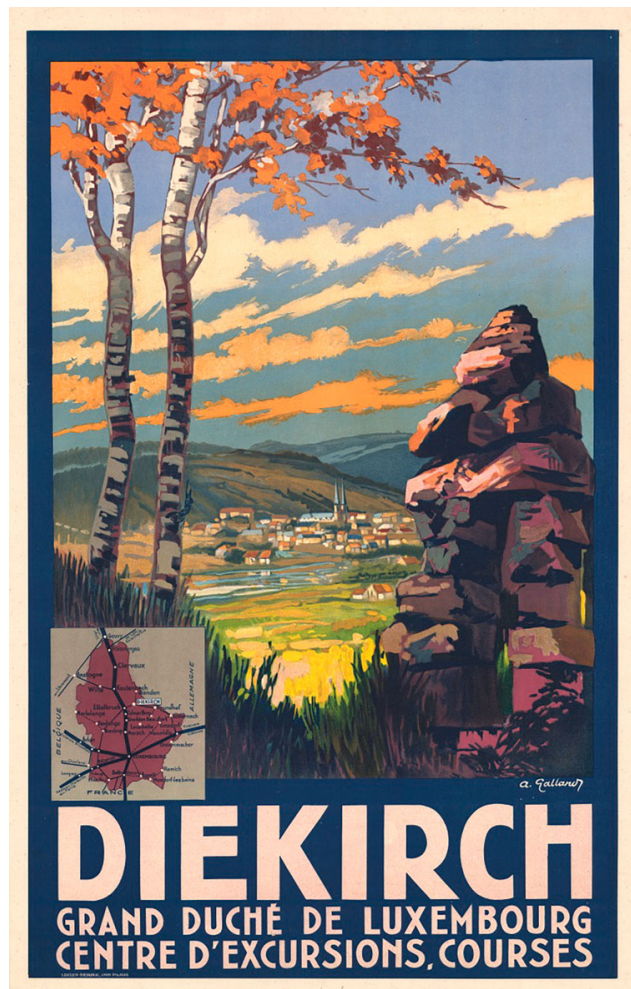

Figure 9. Advertising poster, ca. 1930s. $\mathrm{OBnL}$

the 'mixed culture' as a pretentious self-delusion: 'Oh, they wrestle hard for this Gallic lightness. They are a grounded, firmly enrooted breed of people' ${ }^{90}$ While Kraus does see them as the 'future mediators of Central Europe' because of their 'natural multilingualism', at present they use that asset merely to function as 'the best hotel porters'. ${ }^{91}$ Correcting these blatant and offensive mistakes that litter Kraus's article, Weber points the finger at both the writer and the newspaper for 'filling their pages with such bullshit' (Figure 9). ${ }^{92}$

Journalistic criticisms based on the smallness of the young state particularly infuriated Weber, who consistently fought the association of size and cultural value in and through his feuilleton. In 1930, for instance, he sets out to correct and discredit disparaging comments about the small state and its claims to an independent culture. He recounts the instance that 'these days, a correspondent coined the term 'wannabe-tropolis' for Luxembourg. ${ }^{93}$ The German original 'Gernegrossstadt' presents itself as a pun combining 'gernegross' (wannabe) and 'Grossstadt' (metropolis) and thus mocks the city's aspirations to become a cultural hub. Weber, rather aggressively and seemingly offended, snorts: 'Nothing is cheaper than to mock our striving for metropolitan character'. ${ }^{44} \mathrm{He}$ then

\footnotetext{
${ }^{89}$ lbid.

${ }^{90}$ lbid.

${ }^{91}$ Ibid.

${ }^{92}$ lbid.

${ }^{93}$ Batty Weber, 'Abreißkalender', Luxemburger Zeitung, January 22, 1930, 4151.
} 
seeks to rebuild the communal persona's confidence: 'the capital of a country of 250,000 residents can evidently not become a metropolis like Berlin, Paris or London. Thank God!' ${ }^{95}$ When a certain Dr L. published an article entitled 'Luxembourg: an Autonomous Small State' in the Saarbrücker Zeitung, Weber relativises the importance of size in response: 'Small? What is small supposed to mean? Is a precision chronometer less valuable than a diesel engine just because you can put the one into your pocket, but not the other'? ${ }^{96}$ Insisting not only on the country's raison d'être, but on a spectrum of cultural value, Weber reacts against the widespread tendency to associate size with merit and credibility. He further discredits the tendency to thus quantify legitimacy: 'One should not judge us by the map alone. The rights of the small intrinsically have the same value as those of the very biggest, because rights cannot be measured in square meters' ${ }^{97}$ Insisting on humanism and democracy and rejecting the attacks of inherent backwardness, immaturity and incompetence that Luxembourgers have had to endure based on the small size of their country, he confidently shouts out to his 'newspaper writer colleagues' that '[we are] the provinces that have eclectically crafted a cultural extract from local and foreign elements' ${ }^{98}$ It is uncertain whether Weber's message ever reached the journalists in question, but be that as it may, his feuilletons were clearly instrumental in revaluing Luxembourg's cultural identity after the slights received.

With regards to the perception of Luxembourg abroad, Weber was all the more upset about the inaction of native intellectuals, writers and authorities to refute blemishes to its reputation. The periodical Illustration de la Belgique, du Grand-Duché de Luxembourg et de la Colonie would, in his opinion, have offered an excellent opportunity for self-presentation by showing Luxembourg's point of view on current cultural debates. But contributions from Luxembourg were rare, even in a venue that was created for its benefit and which addressed an international audience:

This journal offers us the most precious opportunity to project the truth about ourselves onto the screen of a wide audience and it is incomprehensible why we do not take it. Again and again, do we witness that blooming nonsense is spread about us abroad. Every foul-mouthed penny-a-liner from the outside feels a calling to send a caricature of us into the world, but we do not reach a foreign audience through any of the venues published here. We have to sit and watch them disfigure us and if, for once, we are given a mouthpiece to make our position heard abroad, we turn around like shy tots and run away sucking our thumbs when a stranger approaches us. ${ }^{99}$

This dismissive comment shows that Weber is neither happy with the portrayal of Luxembourg by foreign writers and journalists, nor with the local attempts at crafting an image of competence and integrity for themselves. He finds the missed opportunity to make Luxembourg visible and known to a wider public as inexcusable as the patronising sense of entitlement he witnesses in derogatory portrayals of the country abroad.

\footnotetext{
${ }^{94}$ Ibid.

${ }^{95}$ Ibid.

${ }^{96}$ Batty Weber, 'Abreißkalender', Luxemburger Zeitung, April 29, 1921, 4499.

${ }^{97}$ Ibid.

${ }^{98}$ Batty Weber, 'Abreißkalender', Luxemburger Zeitung, January 15, 1935, 5485.

${ }^{99}$ Batty Weber, 'Abreißkalender', Luxemburger Zeitung, May 27, 1924, 2664.
} 


\section{Attitudes towards foreign tourists}

Since the growing democratisation of mobility and leisure beginning in the nineteenth century, distinctions have been drawn between travel and tourism, the former being a sign of intellectual cultivation and taste and the latter a mere pleasure-seeking activity, conducted mindlessly and without any learning benefit. Jonathan Culler's observation that scholars analysing the tourist phenomenon tend to adopt this very attitude in their accounts is still relevant today. Otherwise 'superb' studies, such as the works of Dean MacCannell and Daniel Boorstin, perpetuate the dichotomy between 'authentic' travellers, able to discover and connect with the 'real' place, and 'artificial' tourists fooled into a cheap but pricey performance of that place. ${ }^{100}$ Culler thus writes that in a lot of analyses, like in the public mind,

the tourist is the lowest of the low. No other group has such a uniformly bad press and so few defenders. Tourists are continually subject to sneers and have no anti-defamation league. Animal imagery seems their inevitable lot: they are said to move in herds, droves, flocks, or swarms [.] When granted human status they are the least perceptive, the most gullible, and generally the most amazingly foolish of human beings. ${ }^{101}$

Much like the literary fans lionising nineteenth-century celebrities such as Lord Byron or Alfred Lord Tennyson, who also engaged in tourist practices, travelling to writers' private houses, wishing to connect with them, tourists generally are believed to feel contented with an illusion of seeing, of consuming without processing, of pretending and performing but not being.

Despite the respectful attitude towards tourists that Weber displays in most of his texts, he too creates categories and types of tourists based on value judgements. Contrasting bus tour groups composed of 'many joyous people; men with always new travel caps and women in tailor-made suits; all of them rosy-cheeked, talking loudly and laughing heartily' with the serious planning undertaken by the organisers of the Vosges Club, leading from the Moselle to the Oesling, to Luxembourg City and then to Mondorf, Weber sides with the latter who guided their members through the country well-informed. ${ }^{102}$ While the participants of the eight-day bus tours certainly enjoy their stay, Weber is concerned that they might remember mainly the delicious deep-fried fish and the weird taste of the thermal water at Bad Mondorf. Fun, in his eyes, is not quite enough to take away from Luxembourg: 'their merry day was nothing more than a merry day. ${ }^{103}$ Unlike for them, for the members of the Vosges Club, the visit to Luxembourg will be 'of lasting benefit'. ${ }^{104}$

Whether or not a sight is perceived correctly and whether or not that perception can improve the onlooker's knowledge and sensitivity, depends on the latter's attitude towards the attraction. In an early feuilleton, Weber had already mused upon the change in status that a site undergoes upon contemplation:

Is it not strangely arrogant of us that each time we approach a sight; we feel that it has been waiting for us to look at it since time immemorial? Now that we have seen it - now it has served its purpose. When a Sunday tourist stands in front of Bourscheid Castle, he thinks

\footnotetext{
${ }^{100}$ Jonathan Culler, 'The Semiotics of Tourism', Journal of Semiotics 1 (1981), 127-140.

${ }^{101}$ Ibid., 128.

${ }^{102}$ Batty Weber, 'Abreißkalender', Luxemburger Zeitung, May 20, 1933, 5058.

${ }^{103}$ Ibid.

${ }^{104}$ Ibid.
} 
of himself as the main thing. What the Castle of Bourscheid might think, we will, out of respect for the tourist, not imagine. ${ }^{105}$

While Weber voices gentle criticism at the tourist's consumerist attitude towards the sight to be ticked off of what we would today call a 'bucket list', this tourist is not necessarily a visitor from abroad, but might as well be a local exploring the perks of the homeland.

\section{How to stay home: escaping and perceiving the everyday}

Andreas Pott considers tourism at home as an 'atypical borderline case' in which persons encounter their own country as if visiting from abroad. ${ }^{106}$ In this scenario, "the "Here" of the domicile [is] communicated and perceived as a partially unknown "There" that is still to be discovered'. ${ }^{107}$ Seemingly in conflict with the common definition of tourism as an escape from the everyday, tourism at home can indeed offer a break from work routines. Many of Batty Weber's feuilletons, particularly his 'goodbyes' before his summer break, contain invitations to the locals to not 'flock out while the foreigners flock in' and to appreciate the leisure time, natural beauties and entertainment available to them within close reach. ${ }^{108}$ The everyday is seen not as the site of authenticity, but as an obstructive veil uncovering the true beauty of the homeland. If, for Weber, national identity is triggered by the appreciation of the homeland, he implies that the local should adopt a distinctive way of moving through space, of looking at it and of being emotionally moved by it. National identity does not only denote the existence of a shared mental construct, but the performance of that construct through spatial appropriation and mobility. Michel de Certeau's distinction between 'place' as 'elements taken into consideration beside one another' and 'space' as 'accentuated by the ensemble of movements deployed within it' is helpful in differentiating between automatic and mindful spatial practices. ${ }^{109}$ The locals working in Luxembourg City, Weber writes, are burdened by 'so much profession that they do not manage to see anything [in the city] but the agglomeration in whose daily grind they are involved'. ${ }^{110}$ Moving between the eversame places, going home from the office or the workshop, they fail to bring their native city to life:

you might walk through the park, or across one of the two bridges; you might throw a glance around but you won't be aware of the landscape, you'll look at the clock of the Pescatore Home or the Savings Bank,

which makes the city more of a 'work colleague' than a cultural location. Only when leaving the trajectory of the everyday and thus 'actuating' place, Weber believes, can knowledge of the homeland occur: ${ }^{111}$

\footnotetext{
${ }^{105}$ Batty Weber, 'Abreißkalender', Luxemburger Zeitung, May 14, 1915, 434.

${ }^{106}$ Andreas Pott, Orte des Tourismus: eine raum- und gesellschaftstheoretische Studie (Bielefeld: transcript, 2007), 115. [My translation]

${ }^{107}$ Ibid.

${ }^{108}$ Batty Weber, 'Abreißkalender', Luxemburger Zeitung, April 19, 1933, 5031.

${ }^{109}$ Michel de Certeau, The Practice of Everyday Life (Berkeley and London: University of California Press, 1984), 115.

${ }^{110}$ Batty Weber, 'Abreißkalender', Luxemburger Zeitung, April 19, 1933, 5031.

${ }^{111}$ De Certeau, The Practice of Everyday Life, 117.
} 


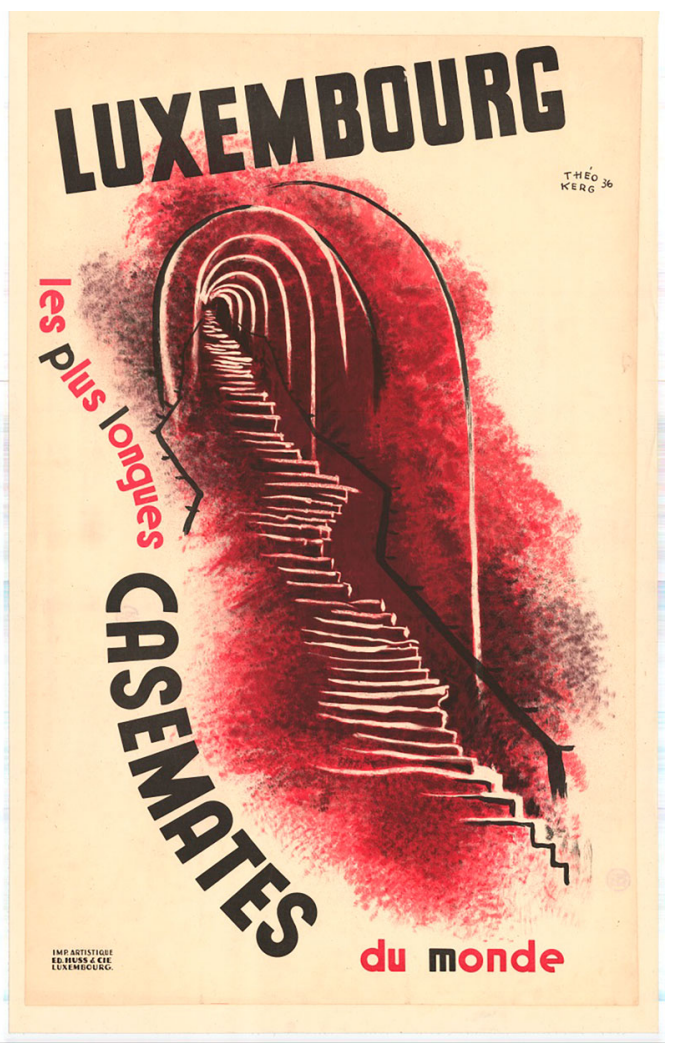

Figure 10. Poster by Théo Kerg advertising the casemates. $\mathrm{OBNL}, 1936$

No other city offers as much picturesque variety to the rambler as Luxembourg [City] does. You can wander in its periphery for hours and drop from one surprise to another. This fact is so well-known that one appears naïve when mentioning it. I still want to ascertain it again, for the many, who will, out of laziness, reject all suggestions with a superior 'I know'. No, they do not know. If, for once, you can get one of them to walk further than the park or to the [Hotel/ Restaurant] Staar by the station, he [or she] is baffled. ${ }^{112}$

For Weber, the conviction or illusion of knowledge prevents the mental and ideological openness necessary for appreciation and admiration. Hence, the blasé attitude of local residents who believe that learning about their country, and consequently about themselves as cultural beings belonging to a nation, is neither possible, nor necessary, inhibits their integration into the national collective. When passing a poster advertising the casemates, a network of passageways hewn into the rock that is a remnant of the fortress, the communal 'we' thinks 'Oh yes, an attraction for foreigners'! ${ }^{113}$ Even though, according to Weber, the casemates represent a 'symbol of peace in spite of their military past', few Luxembourgers would follow the invitation communicated by the poster and have a look. ${ }^{114}$ The 'naturalness of having grown up with' such sights, as well as perhaps the lack of information

\footnotetext{
${ }^{112}$ Batty Weber, 'Abreißkalender', Luxemburger Zeitung, June 30, 1923, 2434.

${ }^{113}$ Batty Weber, 'Abreißkalender', Luxemburger Zeitung, May 20/21, 1934, 5322.

${ }^{114}$ Ibid.
} 
about them, prevents them from seeming unique and therefore interesting. ${ }^{115}$ The local gaze is thus blind to cultural patrimony (Figure 10).

As travel abroad became complicated and even impossible during the First World War, Luxembourgers started exploring their own country with more interest than before. Nevertheless, Weber criticises, his compatriots do not like to veer off the trodden path:

I believe you that you know the places of our homeland that are easy to reach by the ordinary train lines. But those areas that do not border on the military roads of tourism still represent virgin territory for most of us. ${ }^{116}$

Particularly the hilly and thickly wooded North, the Ösling, is generally defined as the 'thin stretch left and right of the Northern railway' and the areas surrounding the tracks are seen as 'uncharted wilderness'. ${ }^{117}$ But, Weber regrets, many people barely even know their own hometown. In order to give his readers a firmer grasp on their immediate surroundings and render them more mindful of their perks and particularities, Weber encourages them to approach the familiar with the gaze of a stranger. He gives them concrete instructions on how to stay at home during the Pentecost holiday:

Stay at home, your ladyship. [ ... ] Use these days to discover your hometown. You know it already? Please allow me to doubt that, your ladyship. You may know it somewhat well from the inside. But get to know it from the outside. Pretend you do not live here. ${ }^{118}$

In order to experience the known as the unknown, the local resident is to perform the relative unbiasedness of the stranger's gaze. For this to be possible, Weber recommends to pack a bag, take a room and ask the waiter about sights worth seeing. Excursions might lead local tourists to places they had 'no idea about' but also past their own house, when they might catch themselves thinking: 'Oh, it must be nice to live there'! ${ }^{119}$ The distance between touristic travel and everyday routines that Weber describes enables the desirably impersonal look onto the self.

As opposed to navel-gazing self-involvement, the performance of tourist practices allows for a simultaneously new and expected appreciation of the real. Repeatedly, Weber tells his readers to break out of the blinding routines of everyday life in order to experience 'the hidden beauties' of, in this particular case, Luxembourg City. ${ }^{120} \mathrm{~A}$ change in gaze is necessary to see and appreciate their cultural value and they need to be approached as if they were 'works of art'. ${ }^{121}$ He encourages his audience to delve into the endless variety of visual combinations encountered during directionless rambling:

Take your walking stick and walk. Leave through any one of the gates, East or West, South or North, the frame and the image presenting themselves will be so diverse that you will never come home from an excursion without a lasting impression. ${ }^{122}$

With an openness that can be compared to that of a camera obscura, the gaze of the local tourist who explores his surroundings without an agenda confronts the city's

\footnotetext{
${ }^{115}$ Ibid.

${ }^{116}$ Batty Weber, 'Abreißkalender', Luxemburger Zeitung, April 13, 1918, 1154.

${ }^{117}$ Ibid.

${ }^{118}$ Batty Weber, 'Abreißkalender', Luxemburger Zeitung, May 15/16, 1921, 1912.

${ }^{119}$ Ibid.

${ }^{120}$ Batty Weber, 'Abreißkalender', Luxemburger Zeitung, March 16, 1932, 4735.

${ }^{121}$ Ibid.

${ }^{122}$ lbid.
} 
structures from ever new angles and perspectives. Weber himself periodically strolled through the city 'as if I was a foreign tourist' in order to open himself to up a vision detached from the everyday. ${ }^{123}$ What might be called the tourist gaze of the local indeed 'depends upon what it is contrasted with' and in this case needs to be stripped of the everyday. ${ }^{124}$ Meanwhile, the tourist gaze of the proper tourist, as described by Urry, is constantly searching for such elements of the everyday that promise an authentic experience. Weber's idea of the tourist gaze as more authentic than the local gaze (not to be confused with the 'local gaze' as defined by Darya Maoz as the perception of the tourist by the locals) fundamentally raises the status of the tourist and credits him or her with the enviable neutrality of vision. ${ }^{125}$

\section{Conclusion}

Recent work in tourism studies has highlighted the impact of political realities on tourist practices. ${ }^{126}$ This article participates in these timely debates, accentuating the doublestatus of the generalised tourist figure as the meaning-giving other and as the emulably receptive camera obscura consuming the unique visual beauty the country has to offer. Weber's narrative of nationhood highlights the connection between self-knowledge and visual experience, portraying the active involvement of town-planners, hoteliers, restauranteurs and journalists as essential to the outside signification that goes into national identity. By suggesting ways to steer the external perception, Weber seeks to return agency to the Luxembourgers whom he sees as holding back their full potential due to shyness, lack of self-confidence and insufficient risk-taking. Perhaps due to the deeplyingrained tendency to value modesty over self-assertion, apparent in the speeches of the Minister of Tourism Nicolas Margue in 1938, the lack of historical groundedness, or the minority complex of a small nation, Luxembourg, in Weber's eyes, did not tap into its full potential as a tourist destination or as a nation. ${ }^{127}$ In this sense, the improvement of the tourist experience seemed like a practicable way of raising the esteem of Luxembourg as a nation both abroad and at home.

\section{Disclosure statement}

No potential conflict of interest was reported by the author.

\section{Funding}

This work was supported by the National Research Fund of Luxembourg [C12/CS/3967435/FCIL/ Millim].

\footnotetext{
${ }^{123}$ Batty Weber, 'Abreißkalender', Luxemburger Zeitung, July 29, 1932, 4847.

${ }^{124}$ John Urry, The Tourist Gaze, 1.

${ }^{125}$ Darya Maoz, 'The Mutual Gaze', Annals of Tourism Research 33/1 (2006), 221-239, 222.

${ }^{126}$ Eric G. E. Zuelow, 'Editor's Introduction', Journal of Tourism History 1-2 (2015), 1-4.

${ }^{127}$ Nicolas Margue, 'Préface', in Touring Club Luxembourgeois, Touring Club Luxembourg, ed. (Luxembourg: P. Linden, 1938$), 3$.
} 


\section{Notes on contributors}

Dr Anne-Marie Millim is a researcher in multilingual literature, specialising in autobiographical and non-fictional genres, such as diaries, auto/biographies and the many forms of press discourse. She has published widely on the connection of landscape, the perception of physical reality and national identity. She has a Ph.D. in Victorian literature and is the author of The Victorian Diary: Authorship and Emotional Labour (Ashgate, 2013) and co-author of Victorian Celebrity Culture and Tennyson's Circle (Palgrave, 2013). 